\title{
Wound Healing Potentials of some Fin Fishes
}

\author{
Ogaga Augustine Aghoghovwia ${ }^{1}$, EJ Uhunmwangho ${ }^{2}$, Sylvester Chibueze Izah $^{3 *}$ \\ ${ }^{I}$ Department of Fisheries and Aquatic Studies, Faculty of Agriculture, Niger Delta University, Wilberforce \\ Island, Bayelsa State, Nigeria \\ ${ }^{2}$ Department of Medical Laboratory Science, Faculty of Basic Medical Sciences, Ambrose Alli University, \\ Ekpoma, Edo state, Nigeria \\ ${ }^{3}$ Department of Biological Sciences, Faculty of Science, Niger Delta University, Wilberforce Island, Bayelsa \\ State, Nigeria \\ *Corresponding Author: Sylvester Chibueze Izah, Department of Biological Sciences, Faculty of \\ Science, Niger Delta University, Wilberforce Island, Bayelsa State, Nigeria
}

\begin{abstract}
Fish is an important source of animal protein. Fish have been widely been exploited by human as food and pharmaceutical sector. Fin fish are distinguished from other fishes (shellfish) by the presence of distinctive anatomical features such as fins and gills. Fishes have been reported to confer several medicinal properties. This study reviewed fin fishes with wound healing potentials. The study showed that fresh water fishes like Channa striatus, Clarias gariepinus, Oncorhynchus mykiss and Cyprinus carpio has mucilaginous compounds that helps as laxative and in healing wounds. Specifically, slime coat of Clariasgariepinus contain mucin that possess antimicrobial properties. Marine fin fish such as Otolithes ruber, Magalaspis cordyla and Oreochromis niloticus possess different forms of collagens that play essential role in wound healing. Therefore, there is the need for research to focus on the isolation and purification of the exact constituents of the fishes that possesses wound healing potentials.
\end{abstract}

\section{INTRODUCTION}

The human skin protects the tissues and organs from physical, mechanical, chemical and microbial damage and they mainly consist of the epidermis, dermis and subcutaneous tissue (Da et al., 2017; Bi and Jin, 2013). Skin injury often cause disruption of neutrophils, monocytes and macrophages on the site of injury (Barrientos et al., 2008; Akunne et al., 2016).Wound infection is one of the health concerns that are caused and aggravated by the invasion of pathogenic microorganisms (Mama et al., 2014). Generally wound infections create barrier during restoration of the skin due to abrupt loss of integrity of the skin. This could lead to adverse impact on the patient's quality of life as well as on the healing rate of the wound (Mama et al., 2014).

Several types of wound occurs including traumatic wounds (viz: cuts, punctures, lacerations or scrapes etc) which can also be classified into penetrating, cut and acute wounds (Giametti et al., 2000), surgical wound (viz: cut or incision in the skin made by a scalpel blade during surgery) and can be classified into four that is Class I (wounds that is clean both in sight and aseptic presenting no inflammation and are mainly found in the eye, skin and the vascular system), Class II (wounds that appear clean and shows no sign of contamination but usually at risk of been infected due to their location (gastrointestinal tract), Class III (wound that comes in contact with unsterile outside object such as gunshot wound) and Class IV (surgical wound that is considered dirty either during or after surgery probably due to environmental factors (De Pietro, 2016), burn wounds (viz: skin injuries caused by fire, light, heat, radiation, electricity, chemical and volcanicity) etc. Furthermore, Obi (2015) classified wound into accidental, pathological or post-operative. Da et al. (2017), Patrulea et al. (2015) also classified wound based on its thickness including superficial, partial-thickness and fullthickness.

Wound infection is one of the health concerns that are caused and aggravated by the invasion of pathogenic microorganisms (Mama et al., 2014). Generally wound infections creates barrier during restoration of the skin due to abrupt loss of integrity due to wound. This could lead to adverse impact on the patient's quality of life as well as on the healing rate of the wound (Mama et al., 2014). 
The cause, source, size or depth of the injury cannot be underrated in clinical practice. Several factors are known to enhance healing of wound including hygiene status of the wound (clean, contaminated or dirty). Uncontaminated wound could suggest unlikely chance of inflammation which tends to heal faster probably due to the absence of pus among other factors.

Several species of microbes have been reported in wound infection (Thanni et al., 2003; Shittu et al., 2002; Okesola and Kehinde, 2008; Obi, 2015; Muhammad et al., 2014; Iregbu et al., 2013; Gadzama et al., 2007). Sensitivity profile has been widely carried out on the pathogens found in wound infections (Taiwo et al., 2002; Obi, 2015; Iregbu et al., 2013). The level of microbial infestation with regard to diversity and density also influence the wound healing rate. Like most pathogenic organisms, when their population is high, it tends to contend with the defense mechanism/ system of the host. This is because wound healing requires a good healthy environment so that the normal physiological process will result in normal healing process with slight scar formation (Mama et al., 2014).

The knowledge of wound infections agents is helpful in the selection of empiric antimicrobial therapy and on the infection control measures (Obi, 2015; Thanni et al., 2003). Furthermore, the interplay between host, microbial and other factors eventually determines the prevention of wound infection (Obi, 2015). Studies on the medicinal potentials of plants and animal have increased. But studies on the therapeutic potentials of animals are often reported in literature compared to that of wildlife (Izah and Seiyaboh, 2018). This could be due to claim of traditional medicine practitioner that several species of plants have therapeutic properties against several human diseases and parasites that affects human and other animals. On the other hands wildlife have several healing potentials. Authors have variously reported the role of animals in traditional medicine practice (Ajagun et al., 2017; Ajagun and Anyaku, 2017; Alves, 2008; Alves et al., 2011; Banjo et al., 2002; Costa-Neto, 2005; Mbaya and Malgwi, 2010; Oduntan et al., 2012; Osunsina et al., 2012; Soewu, 2008; Soewu and Ayodele, 2009; Soewu et al., 2012; Saidu and Buij, 2013).

Fishes are a group of live forms that thrives in aquatic ecosystem where they complete all their life forms. Fishes is a major source of animal protein to human (Ineyougha et al., 2015; Izah and Angaye, 2015; 2016; Angaye et al., 2015) and have been widely employed in other downstream applications including feed production. Hence this present study focused on the wound healing potentials of fishes.

\section{FiSHES AND THEIR ROLES IN HUMAN HEALTH}

Fishes are only a source of animal protein required by human but they are been widely used in combatting certain disease condition including would healing. Typically, Ramalingum and Mahomoodally (2014) reported that pharmaceutical and nutritional sciences appear to be coexisting for maintaining normal human health. This is because several food resources are being used in treatment of several types of diseases. In addition medical professionals have recognized the synergism of drug therapy and nutrition in the fight against certain diseases condition (Ramalingum and Mahomoodally, 2014).Studies have been conducted while several others are still ongoing on the prophylactic benefits of food for potential use as novel medicine due to the presence of therapeutic active compounds (Ramalingum and Mahomoodally, 2014).

Like some species of mammals, amphibians, birds, reptiles, fishes plays important role in the management of some disease condition including asthma, mental illness, eye diseases, low birth weight, nutrient deficiencies (Rajani and Alka, 2015). Fish is a major source of animal protein and are included in daily diet of humans. Studies have considered fish as cheap source of animal protein (Ineyougha et al., 2015; Angaye et al., 2015). Studies have indicated that fish contain important nutrients such as vitamins, minerals and proximate compositions (especially protein and lipids/fats) (Rajani and Alka, 2015).

Most fishes with therapeutic potentials are found in both fresh and marine ecosystem. For instance, Venkatesan et al. (2017) reviewed marine fish with medicinal potentials to include Setipinna taty and Scomber scombrus (antimicrobial properties); Scomber austriasicus, Thunnus obesus, Salmon alcalase, Decapterus maruadsi, Johnius belengerii, Paralichthys olivaceus, Magalaspis cordyla, Otolithes ruber, Merluccius productus, Oreochromis niloticus, Hypoptychus dybowskii (bioactive antioxidant peptides potentials); Lagocephalus gloveri, Thunnus obesus, Paralichthys olivaceus, Sebastes schlegeli, Lateolabrax maculatus, Pagrus major, Takifugu rubripes, Sepiella inermis, Lutjanus vitta, Magalaspis cordyla, Otolithes ruber, Evenchelys macrura, Saurida spp., Trachurus 
japonicus, Mugil cephalis, Cypselurus melanurus, Dentex tumifrons, Cyaneano zakii, Sardinella longiceps, Priacanthus tayenus, Priacanthus macracanthus, Parupeneus heptacanthus, Mystus macropterus, Syngnathus schlegeli, Chrysaora sp (collagen on some parts of their body viz: skin, scale, bone, whole body). Furthermore, others studies have indicated that Clarias gariepinus, Anabas testudineus and Channa striatus have medicinal properties.

\section{Fin Fishes with wound Healing Potentials}

Several physiological processes are involved in the repair of skin and other soft tissues injury in humans and other animals (Akunne et al., 2016). The mechanism of wound healing is a complex processes that involve resurfacing, reconstruction and restoration of the tensile strength of the injured tissue at cellular level (Akunne et al., 2016). Wound healing typically involves four major phases viz: haemostasis, inflammation, proliferation and remodeling/ maturation (Akunne et al., 2016; Kerstein, 1997). According to Pastar et al. (2014), Akunne et al. (2016), several processing occurring at both cellular and molecular phase are involved in initiation, maintenance, and completion of epithelialization for complete wound closure.

Chemical components have been used for treatment of wound and research is still ongoing for the development of new synthetic and organic chemicals with effective wound healing. Mathivanan et al. (2012) reported that $10 \%$ and $20 \%$ solution of silver nanoparticles showed the wound healing within 12 and 8 days respectively for wound in the skin of Anabas testudineus. This study focused on fishes with wound healing properties. Several fishes with wound healing potentials are found in marine and freshwater ecosystem.

\subsection{Freshwater Fin Fishes with Wound Healing Potentials}

Freshwater fishes such as Channa striatus and Clarias gariepinus have been widely studied for potentials utilization in injury closure (Table 1). Clarias gariepinus is a common Niger Delta wetland fish that have been widely used in toxicological studies (Inyang et al., 2017; Ogamba et al., 2016). The body of the fresh cat fish is slime. According to Akunne et al. (2016), the slime coat of catfish contain carbohydrates $(76.31 \%)$, moisture content $(10.86 \%)$, proteins $(7.38 \%)$, ash $(2.34 \%)$, fibre $(2.06 \%)$ and fats $(1.06 \%)$ per $100 \mathrm{mg}$ of the mucin, and it has antibacterial efficacy against Staphylococcus aureus, Bacillus subtilis, Escherichia coli, Pseudomona aeruginosa, Salmonella typhi, Klebsiella pneumonia, Candida albicans and Aspergillu sniger. The authors also reported that the slime coat have wound healing potentials. This group of bacteria reported by Akunne et al. (2016) has some similarity with the bacteria isolates that have been isolated from would infections from different regions of the world. Some of this microbial isolates include Staphylococcus aureus, Staphylococcus epidermidis, Coagulase negative Staphylococci, Streptococcus pyogene, $\alpha$-haemolytic Streptococcus, Pseudomonas aeruginosa, Pseudomonas species, Escherichia coli, Enterobacter species, Enterococcus faecalis, Klebsiella aerogene, Klebsiella pneumonia, Klebsiella species, Citrobacter freundi, Proteus vulgaris, Proteus mirabilis, Proteus species (bacteria), Candida albicans (yeast) (Mama et al., 2014; Obi, 2015; Muhammad et al., 2014; Iregbu et al., 2013; Gadzama et al., 2007; Okesola and Kehinde, 2008; Shittu et al., 2002). Staphylococcus aureus, Escherichia coli and Pseudomonas aeruginosa are microbes that often have high occurrence density in wound infection. Mama also reported that Staphylococcus aureus sand Pseudomonas aeruginosa as nosocomial infection that is often associated with surgery and burns (Mama et al., 2014).

Channa striatus often called snakehead fish or Haruan is a freshwater carnivorous supra branchial air breathing fish that is widely found in Malaysia (Mohd and Abdul, 2012; Manan, 2007; Khan et al., 2014). Studies have revealed that the fish has several therapeutic properties including anti-microbial, anti-inflammatory, cell proliferation, induction of platelet aggregation and anti-nociceptive properties of the mucus (Manan, 2007; Shafri and Abdul Manan, 2012; Wahab et al., 2015). Gam et al. (2006) reported that snakehead fish is used as wound healing remedy in Asia Pacific countries. The authors also reported that the fish has the tendency to reduce post-operative pain and discomfort. Like most other freshwater fishes, Channa striatus are cultured and also found in the wild. Nutritional composition include the presence of essential amino acids, fatty acids that that essential for would healing. The specific amino acids are glycine, while the fatty acids are arachidonic acid (Wahab et al., 2015; Baie and Sheikh, 2000 a, b). Mohd and Abdul (2012) also reported the important amino acids of the fish include glycine, lysine and arginine, while its fatty acids are arachidonic acid, palmitic acid and docosahexaenoic acid. These compound is believed to enhance wound healing through initiation 
of several mechanisms involving the collagen remodeling, wound reepithelialisation and induction of wound contraction (Wahab et al., 2015; Mohd and Abdul, 2012; Baie and Sheikh, $2000 \mathrm{a}$, b; Wild et al., 2010; Park et al., 2017).Parts of snakehead fish mostly used include whole fish, mucus and skin of the fish (Mohd and Abdul, 2012).

Rajani and Alka (2015) have also reported that Cyprinus carpio (Common carp), Chanda raga (Indian glassy fish), Heteropneustes fossilis (Stinging catfish), Anabas testudineus (climbing perch), Clarias batrachus (walking catfish) have antimicrobial properties. These fish are found in varying environmental condition. For instance, Schmidt et al. (2013) Cyprinus carpio an omnivorous fish with body weight of $45-50 \mathrm{~kg}$ is a warm water species $\left(20-25^{\circ} \mathrm{C}\right.$ optimum) that survive in freshwater, lakes and slow flowing rivers, often in turbid water, while Oncorhynchus mykiss a carnivorous fish with body weight of $20-25 \mathrm{~kg}$ is a temperate water species $\left(10-15^{\circ} \mathrm{C}\right.$ optimum) that is found in freshwater and it possesses anadromous life-strategy.

Table1. Fresh water fin fishes with wound healing properties

\begin{tabular}{|c|c|c|c|}
\hline Scientific name & Common name & Role & References \\
\hline Clarias gariepinus & Catfish & $\begin{array}{l}\text { The mucoprotein slime coat of catfish possess } \\
\text { wound healing and it also have antibacterial activity } \\
\text { with bactericidal potentials }\end{array}$ & Akunne et al., 2016 \\
\hline Clarias gariepinus & Catfish & $\begin{array}{l}5 \% \text { of catfish mucin ointment showed } 100 \% \\
\text { wound healing properties on the } 12^{\text {th }} \text { day. The } \\
\text { ointment showed a significant higher tensile } \\
\text { strength and hydroxyproline in the skin, with no } \\
\text { record of toxicity }\end{array}$ & Momoh et al., 2013 \\
\hline Channa striatus & $\begin{array}{l}\text { snakehead } \\
\text { murrel }\end{array}$ & $\begin{array}{l}\text { The use of } 500 \mathrm{mg} \text { of snakehead fish extract of } 6 \\
\text { weeks had differences in wound cosmetic } \\
\text { appearance and patient's satisfaction and it is safe } \\
\text { for human consumption. }\end{array}$ & Wahab et al., 2015 \\
\hline Channa striatus & $\begin{array}{l}\text { snakehead } \\
\text { murrel }\end{array}$ & $\begin{array}{l}\text { Channa striatus had raised tensile strength, } \\
\text { epithelialisation, and fibroblastic proliferation in } \\
\text { the healing of laparotomy wound }\end{array}$ & Pasha et al., 2015 \\
\hline Channa striatus & $\begin{array}{l}\text { snakehead } \\
\text { murrel }\end{array}$ & $\begin{array}{l}40 \% \text { and } 50 \% \mathrm{w} / \mathrm{v} \text { of aqueous extract of Channa } \\
\text { striata significantly decreased the volume of gastric } \\
\text { juice and increased the levels of catalase while } \\
\text { considerable decrease in free and total acidities and } \\
\text { increase in superoxide dismutase. The study also } \\
\text { indicated a decline inulcer index and } \\
\text { malondialdehyde. This suggest that the aqueous } \\
\text { extract of Channa striata have anti-secretory and } \\
\text { antiulcer activities }\end{array}$ & Khan et al., 2014 \\
\hline $\begin{array}{l}\text { Oncorhynchus } \\
\text { mykiss }\end{array}$ & Rainbow trout & The fish have tissue regeneration potentials & Schmidt et al., 2013 \\
\hline Cyprinus carpio & Common carp & The fish possess wound healing potentials. & Schmidt et al., 2013 \\
\hline
\end{tabular}

\subsection{Marine Fin Fishes with Wound Healing Potentials}

Several marine fish are used as food source of human. Most fishes that are sold at commercial scale in many markets in Nigeria are from marine ecosystem. Wastes of marine fish are often discharged into the environment where thy cause attendant environmental impacts but studies have suggested that important bioactive ingredients that are beneficial to human health could be isolated from their wastes (Venkatesan et al., 2017). Venkatesan et al. (2017) reported that collagens have been extracted from bone, skin of many marine fish and they have bioactivity toward skin repair and regeneration. The authors further reported that bioactive protein and peptides can also be extracted from marine fish. Authors have widely reported that peptides from fish wastes have antioxidant, antimicrobial, antihypertensive, calcium-binding, and obesity control properties and as such have been applied in cosmeceutical and nutraceutical industries (Najafianand Babji, 2012; Pangestuti and Kim, 2017; Venkatesan et al., 2017),

Collagens have been widely reported in marine fishes. Acid and peptide soluble collagens have been reported Swim Bladders of Miiuy Croaker (Miichthys miiuy) (Zhao et al., 2018), Otolithes ruber and Magalaspis cordyla (Kumar et al. 2012) (Table 2). These suggested that some important constituents of marine fish also promote wood healing. 
Table2. Marine fin fishes with wound healing potentials

\begin{tabular}{|c|c|c|c|}
\hline Scientific name & Common name & Role & References \\
\hline Caranx melampygus & Bluefin Trevally & $\begin{array}{l}\text { The collagen films derived from bones of the } \\
\text { fish have biocompatibility and wound healing } \\
\text { potentials }\end{array}$ & $\begin{array}{l}\text { Rethinam et } \\
\text { al.,2016 }\end{array}$ \\
\hline Otolithes ruber & Tigertooth croaker & $\begin{array}{l}\text { The bone of the fish which is often considered as } \\
\text { a wastes is a source of acid and pepsin soluble } \\
\text { collagens which are cross-linked with } \\
\text { glutaraldehyde and play essential role in wound } \\
\text { healing }\end{array}$ & $\begin{array}{l}\text { Kumar et al., } \\
2012\end{array}$ \\
\hline Magalaspis cordyla & $\begin{array}{l}\text { Finletted mackerel } \\
\text { scad or cordylascad }\end{array}$ & $\begin{array}{l}\text { Bone of the fish is a source of acid and pepsin } \\
\text { soluble collagens which are cross-linked with } \\
\text { glutaraldehyde and it possess three } \\
\text { dimensional pores that aid in wound healing }\end{array}$ & $\begin{array}{l}\text { Kumar et al., } \\
2012\end{array}$ \\
\hline $\begin{array}{l}\text { Oreochromis } \\
\text { niloticus }\end{array}$ & Nile Tilapia & $\begin{array}{l}\text { Marine collagen peptides from the skin of the } \\
\text { fish enhance wound healing processes }\end{array}$ & Hu et al., 2017 \\
\hline
\end{tabular}

\section{CONCLUSION}

In recent time studies into organic material with therapeutic properties have increased. This is as a result of varying difficulty being encountered on surmounting different disease conditions especially disease cause by microorganism. Wound healing is a major task often encountered by health practitioners especially on individual with comorbidity such as diabetes or vascular disease. Probably due to these effects several studies have been conducted to ascertain the role of some constituents of fish on wound healing. To this effect freshwater fish such as Clarias gariepinus, Channa striatus, Oncorhynchus mykiss and Cyprinus carpio; and marine fish such as Otolithes ruber, Magalaspis cordyla and Oreochromis niloticus have bioactive ingredient that promotes would healing. As such this research paper tends to recommend that should be focused on isolation and purification of the exact constituents of the fish that possesses wound healing potentials.

\section{REFERENCES}

[1] Ajagun EJ, Anyaku CE, Afolayan M P. A survey of the Traditional Medical and Non-medical Uses of Animals Species and Parts of the Indigenous people of Ogbomoso, Oyo State. International Journal of Herbal Medicine 2017; 5(3): 26-32

[2] Ajagun J E, Anyaku E C. Conservation Status of Animal Species Used by Indigenous Traditional Medicine Practitioners in Ogbomoso, Oyo State. Journal of Complementary and Alternative Medical Research 2017; 3(4): 1-8.

[3] Akunne TC, Okafor SN, Okechukwu DC, et al. Catfish (Clariasgariepinus) Slime Coat Possesses Antimicrobial and Wound Healing Activities. UK Journal of Pharmaceutical and Biosciences, 2016; 4(3): 81-87.

[4] Alves RR N. Animal-based remedies as complementary medicine in Brazil. Forschende Komplement armedizin, 2008; 15(4): 226-227

[5] Alves RRN, Barbosa JAA, Santos SLDX, et al. Animal-Based Remedies as Complementary Medicines in the Semi-Arid Region of Northeastern Brazil. Evidence-Based Complementary and Alternative Medicine. 2011; doi:10.1093/ecam/nep134.

[6] Angaye TCN, Cosboy M E, Zige DV, et al. Assessment of untreated groundwater against some common fresh water Fish in Bayelsa State, Nigeria. Point Journal of Agriculture and Biotechnology Research. 2015; 1(2):70 - 76

[7] Baie S H, Sheikh K A. The wound healing properties of Channastriatus-cetrimide cream-wound contraction and glycosaminoglycan measurement. Journal of Ethno pharmacology, 2000a; 73(1-2):15-30.

[8] Baie S H, Sheikh K A. The wound healing properties of Channastriatus-cetrimide cream — tensile strength measurement. Journal of Ethno pharmacology, 2000b; 71(1-2): 93-100.

[9] Banjo AD, Lawal OA, Owolana OA, et al. An Ethno-zoological survey of insect and their allies among the Remos (Ogun State). Afr J Indigenous KnowlSyst2002; 2(1):61-67

[10] Barrientos S, Stojadinovic O, Golinko MS, et al. Growth factors and cytokines in wound healing. Wound Repair Regen. 2008; 16(5): 585-601.

[11] Bi H, Jin Y. Current progress of skin tissue engineering: Seed cells, bioscaffolds, and construction strategies. Burns Trauma 2013; 1:63-72.

[12] Costa-Neto E M. Animal-based medicines: biological prospection and the sustainable use of zoo therapeutic resources. Anais da Academia Brasileira de Ciências2005; 77(1): 33-43 
[13] Da L-C, Huang Y-Z, Xie H-Q. Progress in development of bioderived materials for dermal wound healing. Regenerative Biomaterials, 2017, 325-334. doi:10.1093/rb/rbx025.

[14] DePietro M. Surgical-wound. 2016; https://www.healthline.com/health/surgical-wound.

[15] Gadzama GB, Zailani SB, Abubakar SB, et al. Bacterial pathogens associated with wound infections At the University of Maiduguri teaching hospital, Maiduguri, Nigeria, Kanem Journal of Medical Sciences. 2007; 1(1):26-28.

[16] Gam L-H, Leow C-Y, Baie S. Proteomic Analysis of Snakehead Fish (Channastriata) Muscle Tissue. Malaysian Journal of Biochemistry and Molecular Biology 2006; 14: 25-32 25

[17] Hu Z, Yang P, Zhou C, et al. Marine Collagen Peptides from the Skin of Nile Tilapia (Oreochromisniloticus): Characterization and Wound Healing Evaluation. Mar. Drugs 2017, 15: 102; doi: $10.3390 / \mathrm{md} 15040102$.

[18] Ineyougha ER, Orutugu LA, Izah SC. Assessment of Microbial Quality of Smoked Trachurustrachurussold in some Markets of Three South-South States of Nigeria. International Journal of Food Research, 2015; 2: 16 - 23.

[19] Inyang I R, Ollor A O, Izah SC. Effect of Diazinon on Organosomatic Indices and Behavioural Responses of Clariasgariepinus (a Common Niger Delta Wetland Fish). Greener Journal of Biological Sciences, 2017; 7(2): $15-19$

[20] Iregbu KC, Uwaezuoke NS, Nwajiobi-Princewill IP, et al. A profile of wound infections in national hospital Abuja. African Journal of Clinical and Experimental Microbiology 2013; 14(3): 160-163.

[21] Izah SC, Angaye TC N. Ecological perception of fish farmers in Yenagoa Metropolis, Nigeria. Bulletin of Advanced Scientific Research 2015; 1(1): 26 - 28.

[22] Izah SC, Seiyaboh EI. Challenges of wildlife with therapeutic properties in Nigeria; a conservation perspective. International Journal of Avian \& Wildlife Biology, 2018; 3(4):259-264. DOI: 10.15406/ijawb.2018.03.00096

[23] Kerstein MD. The scientific basis of healing. Adv Wound Care. 1997; 10(3):30-36.

[24] Khan MSA, Jais AM, Hussain J, et al. Gastroprotective Effect of Freeze Dried Stripped Snakehead Fish (Channastriata Bloch.) Aqueous Extract against Aspirin Induced Ulcerogenesis in Pylorus Ligated Rats. ISRN Pharmacology. 2014; http://dx.doi.org/10.1155/2014/327606

[25] Kumar NSS, Nazeer R A, Jaiganesh R. Wound Healing Properties of Collagen from the Bone of Two Marine Fishes. International Journal of Peptide Research and Therapeutics, 2012; 18(3):185-192

[26] Mama M, Abdissa A, Sewunet T. Antimicrobial susceptibility pattern of bacterial isolates from wound infection and their sensitivity to alternative topical agents at Jimma University Specialized Hospital, South-West Ethiopia. Annals of Clinical Microbiology and Antimicrobials, 2014; 13:14.

[27] Manan A. Pharmacognosy and pharmacology of Haruan (Channastriatus), a medicinal fish with wound healing properties. BoletínLatinoamericano y del Caribe de PlantasMedicinales y Aromáticas, 2007; 6 (3), 52 - 60

[28] Mathivanan V, Ananth S, Priyanga B, et al. Impact of Silver Nanoparticles on Wound Healing of Freshwater Fish, Anabas testudineus. International Journal of Research in Fisheries and Aquaculture 2012; 2(2): 17-21.

[29] Mbaya Y P, Malgwi H. Species list and status of mammals and birds in Sambisa game reserve, Borno state, Nigeria. Journal of Research in Forestry, Wildlife and Environment, 2010; 2(1): 135 - 140.

[30] Mohd SMA, Abdul MM J. Therapeutic Potential of the Haruan (Channastriatus): From Food to Medicinal Uses. Mal J Nutr2012; 18(1): 125 - 136.

[31] Momoh MA, Brown SA, Muogbo CC. Formulation and Evaluation of Cat Fish Slim Mucin Ointment for Wound Healing. Tropical Journal of Pharmaceutical Research 2013; 12 (6): 885-890

[32] Muhammad U K, Adamu T M, Binji Z et al. Prevalence of pathogenic bacteria isolated from surgical site and wound infection among patients admitted in some selected hospitals in Sokoto metropolis, Nigeria. International Journal of Environment, 2014; 3(3): 89 - 103.

[33] Najafian L, Babji A S. A review of fish-derived antioxidant and antimicrobial peptides: Their production, assessment, and applications. Peptides 2012, 33: 178-185.

[34] Obi C N. Isolation and sensitivity pattern of bacterial isolates of wound infections from patients of Federal Medical Centre, Umuahia, Abia State. Int. J. Curr. Microbiol. App. Sci, 2015; 4(1): 371-379

[35] Oduntan OO, Akinyemi A, Ojo O et al. Survey of Wild Animals Used in Zoo-therapy at Ibadan, Oyo State, Nigeria, Intl. J. of Molecular Zoology, 2012; 2(9): 70-73.

[36] Ogamba E N, Izah SC Isimayemiema F. Bioaccumulation of heavy metals in the gill and liver of a common Niger Delta wetland fish, Clariasgarepinus. British Journal of Applied Research, 2016; 1(1): 17 - 20.

[37] Okesola AO, Kehinde AO. Bacteriology of non-surgical wound infections in Ibadan, Nigeria. Afr J Med Med Sci. 2008; 37(3):261-4.

[38] Osunsina OO, Inah EI, Onadeko SA, et al. Use of wild animals as alternative therapy in support zone village around some Nigeria National parks. Forests and Forest Products Journal, 2012; 5: 7 -18. 
[39] Pangestuti R, Kim S-K. Bioactive peptide of marine origin for the prevention and treatment of noncommunicable diseases. Mar. Drugs 2017; 15: 67.

[40] Park J-H, Choi S-H, Park S-J, et al. Promoting Wound Healing Using Low Molecular Weight Fucoidan in a Full-Thickness Dermal Excision Rat Model. Marine Drugs 2017; 15(4): 112; doi:10.3390/md15040112

[41] PashaMA, Husin R A, Hassan S. The Influence of Oral and Topical Channastriatus on Laparotomy Wound Healing in Malnourished Wistar Rats. International Journal of Pharmaceutical Science Invention, 2015; 4(5): 37-41.

[42] Pastar I, Stojadinovic O, Yin NC, et al. Epithelialization in Wound Healing: A Comprehensive Review. Advances in Wound Care. 2014; 3(7): 445-464

[43] Patrulea V, Ostafe V, Borchard G et al. Chitosan as a starting material for wound healing applications. Eur J Pharm Biopharm 2015; 97: 417-26.

[44] Rajani N, Alka M. To study the Ethano-medicinal importance of food fish used by localite of Durg. IOSR Journal of Environmental Science, Toxicology and Food Technology, 2015; 1 I(6): 38-40

[45] Ramalingum N, Mahomoodally MF. The Therapeutic Potential of Medicinal Foods. Advances in Pharmacological Sciences. 2014; http://dx.doi.org/10.1155/2014/354264.

[46] Rethinam S, Nivedita P, Hemalatha T, et al. A Possible Wound Dressing Material from Marine Food Waste. The International Journal of Artificial Organs. 2016;

[47] Saidu Y, Buij R. Traditional medicine trade in vulture parts in northern Nigeria. Vulture News, 2013; 65: 4 - 14

[48] Schmidt J G, Nielsen M E, Ersbøll B K. Wound healing in rainbow trout (Oncorhynchusmykiss and common carp (Cyprinuscarpio): with a focus on gene expression and wound imaging. Technical University of Denmark (DTU), 2013.

[49] Shafri M A M, Abdul Manan M J. Therapeutic potential of the haruan (Channastriatus): from food to medicinal uses.Malaysian Journal of Nutrition, 2012; 18(1): 125-136.

[50] ShittuAO, Kolawole D O, Oyedepo E A R. A study of wound infections in two Health Institutions in IleIfe, Nigeria. African Journal of Biomedical Research 2002; 5: 97-102.

[51] Soewu DA, Adekanola T A. Traditional-medical knowledge and perception of pangolins (Manissps) among the Awori people, Southwestern Nigeria. J EthnobiolEthnomed2011; 7(25):1-11

[52] Soewu DA, Ayodele I A. Utilisation of Pangolin (Manissps) in traditional Yorubic medicine in Ijebupronvince, Ogun State, Nigeria. J EthnobiolEthnomed2009; 5(39):1-11

[53] Soewu DA, Bakare O K, Ayodele I A. Trade in Wild Mammalian Species for Traditional Medicine in Ogun State, Nigeria. Global Journal of Medical Research, 2012 12(3): 6 -21

[54] Soewu D A. Wild animals in ethnozoological practices among the Yorubas of southwestern Nigeria and the implications for biodiversity conservation. African Journal of Agricultural Research 2008; 3 (6): $421-427$

[55] Taiwo S, Okesina A, Onile B. In vitro antimicrobial susceptibility pattern of bacterial isolates from wound infections inUniversity of Ilorin Teaching Hospital. African Journal ofClinical Experimental Microbiology; 2002; 3 (1) 6-10.

[56] Thanni LOA, Osinupebi OA, Deji-Agboola M. Prevalence of bacterial pathogens in infected wounds in a tertiary hospital, 1995-2001: any change in trend?. Journal of the National Medical Association 2003; 95(12): 1189 - 1195.

[57] Venkatesan J, Anil S, Kim S, et al. Marine Fish Proteins and Peptides for Cosmeceuticals: A Review. Mar. Drugs 2017; 15: 143; doi:10.3390/md15050143

[58] Wahab SZA, Kadir AA, Hussain NHN, et al. The Effect of Channastriatus (Haruan) Extract on Pain and Wound Healing of Post-Lower Segment Caesarean Section Women. Evidence-Based Complementary and Alternative Medicine, 2015; http://dx.doi.org/10.1155/2015/849647

[59] Wild T, Rahbarnia A, Kellner M, et al. Basics in nutrition and wound healing. Nutrition2010;26: 862-866

[60] Zhao W-H, Chi C-F, Zhao Y-Q et al. Preparation, Physicochemical and Antioxidant Properties of Acidand Pepsin-Soluble Collagens from the Swim Bladders of Miiuy Croaker (Miichthysmiiuy). Mar Drugs. 2018; 16(5): pii: E161. doi: 10.3390/md16050161.

Citation: Ogaga Augustine Aghoghovwia et.al, "Wound Healing Potentials of some Fin Fishes", International Journal of Research Studies in Biosciences (IJRSB), vol. 6, no. 5, pp. 33-39, 2018. http://dx.doi.org/10.20431/2349-0365.0605005

Copyright: () 2018 Authors. This is an open-access article distributed under the terms of the Creative Commons Attribution License, which permits unrestricted use, distribution, and reproduction in any medium, provided the original author and source are credited. 